\title{
APLIKASI VARIASI LAMA MASERASI BUAH MANGROVE Avicennia marina SEBAGAI BAHAN PENGAWET ALAMI IKAN NILA (Oreochromis sp.)
}

\author{
Fenny Utari, Nurlaila Ervina Herliany, Bertoka Fajar SP Negara, \\ Aradea Bujana Kusuma, Maya Angraini Fajar Utami \\ Program Studi IImu Kelautan Universitas Bengkulu \\ E-mail : utarifenny@gmail.com
}

Received August 2018 Accepted September 2018

\begin{abstract}
ABSTRAK
Pengawetan merupakan salah satu proses untuk mempertahankan kesegaran mutu pada ikan. Penyebab utama proses kemunduran mutu pada ikan adalah aktivitas mikroba yang terdapat pada tubuh ikan. Penelitian ini bertujuan untuk memperolehlama maserasi buah mangrove Avicennia marina yang optimal sebagai pengawet ikan nila. Penelitian ini dilakukan dengan tiga tahap, yaitu tahap persiapan, tahap maserasi dan tahap aplikasi menggunakan Rancangan Acak Lengkap (RAL) dengan perlakuan : tidak diaplikasikan dengan maserat buah mangrove $A$. marina (K) dan diaplikasikan dengan maserat buah mangrove $A$. marina yang direndam selama $12(A), 24(B)$ dan $36(C)$ jam. Analisis yang digunakan adalah Analisis sidik ragam (ANOVA) pada tingkat kepercayaan 95\%, dan jika terjadi beda nyata maka dilanjutkan dengan uji lanjut Duncan. Hasil penelitian menunjukkan bahwa kadar $\mathrm{pH}$, kadar protein dan uji organoleptik pada ikan menunjukkan bahwa ikan nila yang tidak direndam dalam maserat buah mangrove (kontrol) menghasilkan nilai yang lebih rendah dibandingkan dengan ikan nila yang diaplikasikan dengan maserat buah mangrove. Berdasarkan analisis sidik ragam (ANOVA) perlakuan memberikan pengaruh beda nyata terhadap kadar $\mathrm{pH}$, kadar protein, dan nilai organoleptik ikan. Secara umum, kadar $\mathrm{pH}$, kadar protein, dan nilai organoleptik menunjukkan nilai optimal pada perlakuan pemberian maserat hasil maserasi 12 jam.
\end{abstract}

Kata Kunci : A. marina, Maserasi, Organoleptik, pH, Protein

\section{ABSTRACT}

Preservation is a process to keep the freshness of fish. Microbe activity is the main cause of quality decrease on fish. The purpose of this research was known the optimal maceration time of fruit Avicennia marina as natural preservative. This research obtained on three phase, which are, preparation, maceration, and application used RAL that treatmented: 
without application of maceration (K), applicated with maceration along 12 hours $(A)$, applicated with maceration along 24 hours $(B)$, and applicated with maceration along 36 hours (C). ANOVA and Ducan were used in this research. The results shown $\mathrm{pH}$, protein, and organoleptic indicated that not maceration treatment have more lower results than with application on mangrove fruit. The ANOVA test found that treatment give different results on $\mathrm{pH}$, protein and organoleptic. Generally, $\mathrm{pH}$, protein, and $f$ organoleptic were optimum with maceration during 12 hours.

Keywords : A. marina, Maceration, Organoleptic, $\mathrm{pH}$, Protein

\section{PENDAHULUAN}

Kemunduran mutu ikan tak dapat dipungkiri sebab ikan merupakan produk yang high perishable (mudah rusak) sehingga memerlukan penanganan khusus. Penyebab utama proses kemunduran mutu pada ikan adalah aktivitas mikroba yang terdapat pada tubuh ikan. Sebelum terjadinya kemunduran mutu, ikan harus cepat ditangani atau diolah dengan baik sehingga diperlukan upaya agar bahan makanan tersebut dapat diterima oleh konsumen dalam keadaan yang masih layak konsumsi (Wibowo dan Yunizal, 1998).

Pengawetan memiliki fungsi untuk menghambat atau menghentikan beberapa aktivitas bakteri pembusuk dalam tubuh ikan. Proses pengawetan dikelompokkan menjadi dua yakni pengawetan secara alami dan pengawetan secara sintetis. Pengawetan sintetis merupakan pengawetan secara kimia yang menimbulkan efek samping dari bahan tersebut akan memicu pertumbuhan sel pada manusia akibat zat karsinogenik dalam pengawet (Susilo, 2013) untuk itu diperlukan suatu pengawetan yang baik dan aman untuk memperpanjang daya simpan bahan pangan yaitu dengan menggunakan pengawet alami.

Tanaman mangrove (bakau) yang dikenal memiliki senyawa sebagai antibakteri diantaranya jenis Avicennia marina umumnya dikenal sebagai pohon bakau api-api dari jenis Avicenniaceae. "Tumbuhan ini menyediakan sumber yang kaya akan steroid, triterpen, saponin, flavonoid, alkaloid dan tanin" (Subasheree, 2010).

Penelitian mengenai pengawetan alami ikan menggunakan buah mangrove $A$. marina sebelumnya telah dilakukan oleh Pariansyah (2017) menunjukkan bahwa ekstrak buah mangrove $A$. marina (api-api) dengan lama maserasi selama 24 jam mengandung bahan bioaktif berupa alkaloid, terpenoid, saponin, flavonoid dan tanin yang dapat dijadikan pengawet untuk menghambat penurunan mutu kesegaran ikan nila hingga 8 hari yang disimpan dengan suhu dingin.

Berdasarkan pernyataan di atas dan belum banyaknya penelitian mengenai pengawetan alami ikan menggunakan buah mangrove $A$. marina dirasakan perlunya dilakukan penelitian lebih lanjut mengenai "Aplikasi Variasi Lama Maserasi Buah Mangrove A. marina Sebagai Bahan Pengawet Alami Ikan Nila (Oreochromis sp.)". Penelitian ini 
bertujuan untuk memperoleh lama maserasi buah mangrove $A$. marina yang optimal sebagai pengawet alami ikan nila. Penelitian ini diharapkan dapat dijadikan bahan informasi mengenai lama maserasi buah mangrove A. marina yang dapat memperpanjang daya tahan ikan nila.

\section{MATERI DAN METODE}

\section{Waktu dan Tempat Penelitian}

Penelitian ini dilaksanakan pada bulan Februari-Maret 2018 di Laboratorium Perikanan dan Laboratorium Peternakan Universitas Bengkulu. Sampel buah mangrove yang digunakan diambil di ekosistem mangrove Pulau Baai Kota Bengkulu.

\section{Tahap Persiapan}

Langkah-langkah yang dilakukan pada tahap persiapan adalah sebagai berikut (Pariansyah, 2017) :

1. Cuci bersih buah mangrove segar yang telah diperoleh menggunakan aquades, selanjutnya kupas buah mangrove menggunakan pisau hingga berukuran ketebalan sekitar $0,25 \mathrm{~cm}$. Proses pengupasan buah mangrove berfungsi untuk membantu memudahkan proses pengeringan buah mangrove tersebut.

2. Buah mangrove yang telah dikupas lalu dikeringkan menggunakan oven listrik selama 10 jam dengan suhu $70^{\circ} \mathrm{C}$.

3. Setelah memperoleh sediaan kering buah mangrove lalu disimpan dalam wadah kering untuk selanjutnya digunakan dalam tahap maserasi.

\section{Tahap Maserasi}

Maserasi buah mangrove $A$. marina, yaitu dengan melakukan perendaman sediaan buah mangrove kering didalam akuades selama 12 , 24 dan 36 jam pada suhu kamar dengan perbandingan $2: 4$ (w : v/gram : liter). Setelah perendaman selesai, air hasil rendaman diambil untuk diaplikasikan sebagai bahan pengawet ikan.

\section{Tahap Aplikasi}

Pada tahap ini menurut Pariansyah (2017) terlebih dahulu yang dilakukan adalah menyiapkan sampel ikan nila. Ikan nila yang digunakan berukuran 150-160 gram, yang diperoleh dari tempat budidaya ikan dalam keadaan hidup. Kemudian ikan tersebut dibawa ke Laboratorium Perikanan untuk selanjutnya dimatikan dan dibersihkan. Pada proses pembersihan, isi perut ikan dibuang tetapi bagian insang tidak dibuang lalu dicuci. Lalu melakukan tahap aplikasi dengan cara merendam ikan nila didalam maserat buah mangrove yang didapatkan pada tahap sebelumnya selama 2 jam. Ikan nila yang telah direndam dalam maserat 
mangrove kemudian di simpan di dalam plastik dan diberi label. Setelah di simpan dalam plastik dan diberi label selanjutnya ikan disimpan di lemari pendingin dengan suhu $\pm 7^{\circ} \mathrm{C}$ selama 10 hari.

\section{Variabel Pengamatan}

\section{Uji pH}

Pengukuran $\mathrm{pH}$ dilakukan dengan $\mathrm{pH}$ meter sesuai petunjuk Bloom (1988). Pengujian pH menggunakan pH meter elektronik. Prosedur yang digunakan yaitu membersihkan katoda indikator menggunakan aquades hingga tertera $\mathrm{pH}$ bernilai netral ( $\mathrm{pH}$ angka 7) lalu dibersihkan dengan tissue. Selanjutnya menghidupkan $\mathrm{pH}$ meter dengan menekan tombol ON/OFF pada alat. Kemudian menyiapkan sampel daging ikan nila sebanyak 3-4 gram yang telah dihaluskan dan dicampur dengan aquades sebanyak $100 \mathrm{ml}$ didalam gelas beker. Terakhir atur katoda indikator hingga posisi nol dan mencelupkannya ke dalam sampel sampai mendapatkan nilai $\mathrm{pH}$ yang sebenarnya dari sampel ikan nila.

\section{Uji Protein}

Tahapan yang dilakukan dalam analisis protein, yaitu destruksi, destilasi, dan titrasi. Pengujian protein dilakukan pada daging ikan nila menggunakan metode Mikro Kjehdahl.

Destruksi

Destruksi dilakukan dengan menimbang sampel 0,05 gr, lalu masukkan sampel ke dalam labu destruksi yang bersih dan kering, dan ditambahkan katalisator silenium 0,5 gr yang ditambahkan $2 \mathrm{ml} \mathrm{H}_{2} \mathrm{SO}_{4}$ pekat selanjutnya dipanaskan dalam ruangan asam dengan suhu $45^{\circ} \mathrm{C}$ hingga warnanya jernih (tidak ada karbon) lalu didinginkan.

Destilasi

Setelah didapatkan hasil dari destruksi kemudian dimasukkan ke dalam labu destilasi sambil ditambahkan aquades sedikit demi sedikit, penambahan aquades $\pm 1 / 2$ labu destilasi. Selanjutnya ditambahkan $10 \mathrm{ml}$ $\mathrm{NaOH} 40 \%$ dan indikator pp 3 tetes, kemudian ditutup dan dipanaskan. Hasil sulingan ditampung dalam erlenmeyer yang berisi asam borat yang ditambahkan indikator BTB (warna kuning). Kemudian lakukan tes pada cairan yang keluar dari ujung destilator menggunakan kertas saring yang telah ditetesi indikator pp. Setelah berubah menjadi warna hijau dengan volume $\pm 15 \mathrm{ml}$ maka Destilasi dihentikan, sebelumnya cairan yang keluar dari ujung destilator dites dengan kertas saring yang telah ditetesi indikator pp, kemudian tetesi dengan cairan yang keluar dari ujung destilator. Apabila kertas saring tidak berubah warna, maka destilasi dihentikan. Cairan yang keluar tersebut menunjukkan $\mathrm{pH}$ netral, maka destilasi telah selesai. 
Titrasi

Hasil destilasi kemudian dititrasi dengan $\mathrm{HCl}$ 0,02 $\mathrm{M}$ dan titik akhir titrasi ditandai dengan destilat berubah warna kuning. Blanko juga dikerjakan dengan cara yang sama.

Perhitungan :

Kadar N $(\% \mathrm{wb})=\frac{(\text { mlHCIBahan }- \text { mlBlanko }) \times N H C L \times 14,007 \times 100}{\text { mgsampel }}$

Kadar Protein $(\%$ wb) $=$ Kadar N X F

Keterangan :

$\mathrm{F}=$ Faktor konversi protein $(6,25)$

\section{Uji Organoleptik}

Pelaksanaan uji organoleptik berdasarkan SNI 01-2346-2006, dengan penilaian organoleptik untuk ikan segar yang meliputi spesifikasi mutu mata, insang, lendir, bau, tekstur, dan daging (warna dan kenampakan). Pelaksanaan uji organoleptik dilakukan dengan menggunakan panelis standar sebanyak 25 orang.

\section{Rancangan Percobaan Dan Analisis Data}

Pada percobaan ini menggunakan Rancangan Acak Lengkap (RAL) dengan perlakuan : tidak diaplikasikan dengan maserat buah mangrove $A$. marina $(\mathrm{K})$ dan diaplikasikan dengan maserat buah mangrove $A$. marina yang direndam selama $12(\mathrm{~A}), 24(\mathrm{~B})$ dan $36(\mathrm{C})$ jam. Masing-masing perlakuan diulang sebanyak 2 kali.

Variabel penelitian yang digunakan meliputi variabel bebas dan terikat. Variabel bebas adalah aplikasi maserat buah mangrove $A$. marina. Variabel terikat pada penelitian ini adalah kandungan $\mathrm{pH}$, kandungan protein dan nilai organoleptik ikan nila. Data kadar $\mathrm{pH}$, protein, dan organoleptik yang didapatkan dianalisis dengan menggunakan Rancangan Acak Lengkap (RAL) pada tingkat kepercayaan 95\%. Apabila terdapat perbedaan, maka dilanjutkan dengan uji lanjut DMRT (Duncan Multiple Range Test) untuk melihat perlakuan mana yang berbeda. Model matematika untuk Rancangan Acak Lengkap (RAL) menurut Gomez and Gomez (1984) adalah :

$$
Y_{i j}=\mu+T_{i}+\varepsilon_{(i) j}
$$

Keterangan :

$\mathrm{Y}_{\mathrm{ij}}=$ Pengamatan pada satuan percobaan ke-j dan pada ulangan ke-i

$\mu=$ Nilai rataan total

$\mathrm{T}_{\mathrm{i}}=$ Pengaruh faktor perlakuan ke-i 
$\varepsilon_{\mathrm{ij} .}=$ Penyimpangan pengamatan ke-(ij) dari rataan perlakuan, yang juga disebut komponen residu atau galat percobaan

Hipotesis yang digunakan adalah :

$\mathrm{Ho}=$ Pemberian berbagai maserat buah mangrove $A$. marina tidak mempengaruhi daya simpan ikan.

$\mathrm{H} 1=$ Pemberian berbagai maserat buah mangrove $A$. marina mempengaruhi daya simpan ikan.

\section{HASIL DAN PEMBAHASAN}

\section{Derajat Keasaman (pH)}

Menurut Sasmito (2006), pH adalah salah satu parameter untuk menentukan kemunduran mutu ikan dengan cara mengukur banyaknya ion H. Chamidah dan Rosidi (2000), menyatakan bahwa selama penyimpanan terjadi penguraian protein menjadi senyawa basa antara lain amoniak. Nilai pH bahan pangan selama penyimpanan dapat berubah karena adanya protein yang terurai oleh enzim proteolitik dan bantuan bakteri menjadi asam karboksilat, asam sulfida, amoniak dan jenis asam lainnya.

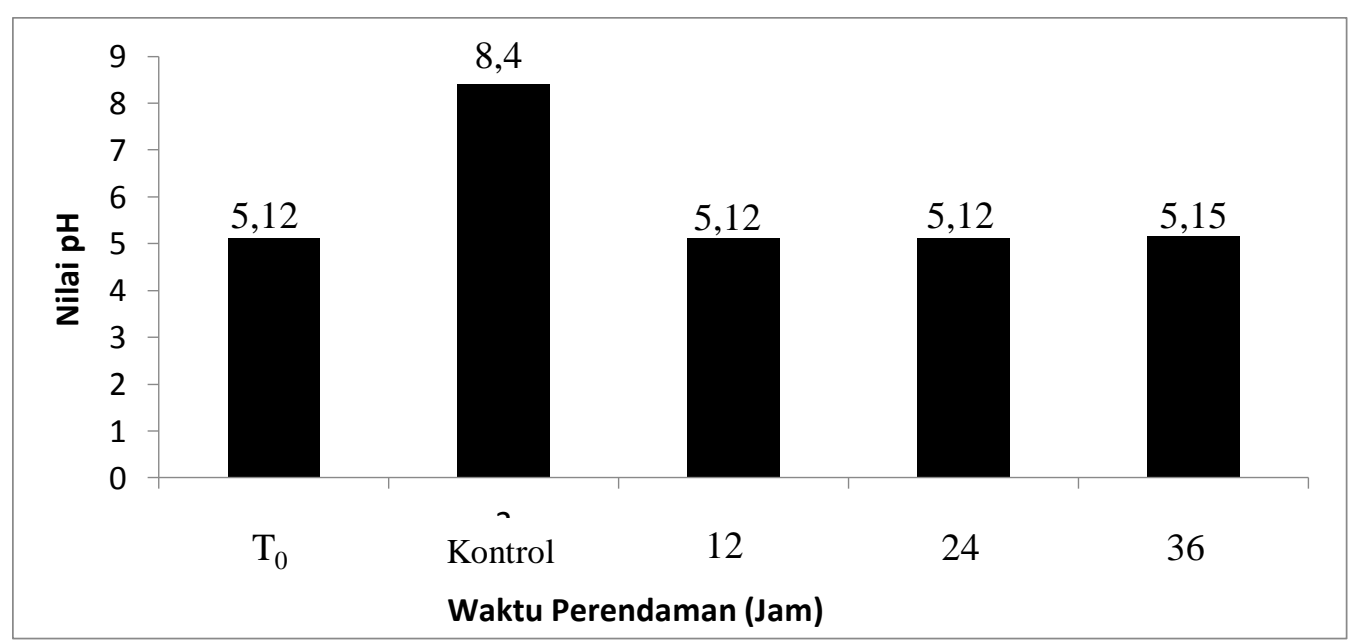

Gambar 1. Grafik nilai pH pada ikan nila (Oreochromis sp.)

Berdasarkan Gambar 1, kadar pH ikan nila yang direndam dalam maserat buah mangrove $A$. marina berkisar antara 5,12 sampai 5,15 dan nilai kadar $\mathrm{pH}$ ikan nila pada kontrol yaitu 8,4. Daging ikan yang mempunyai nilai $\mathrm{pH}$ tinggi disebabkan karena timbulnya senyawasenyawa yang bersifat basa seperti amoniak, trimetilamin, dan senyawasenyawa volatile lainnya yang juga dapat menurunkan nilai organoleptik dari produk (Hadiwiyoto, 1993). Pada fase ini terdapat rangkaian perubahan kimia yang kompleks di dalam otot ikan sehingga sirkulasi 
darah berhenti dan oksigen yang masuk berkurang dan akan terjadi perubahan glikogen menjadi asam laktat. Perubahan ini menyebabkan $\mathrm{pH}$ tubuh ikan menurun dari yang semula 6,9-7,2 diikuti penurunan jumlah ATP. Setelah fase rigomortis berakhir dan pembusukan bakteri berlangsung, maka pH daging ikan naik mendekati netral hingga 7,5-8.

Berdasarkan data yang diperoleh terlihat bahwa nilai $\mathrm{pH}$ pada semua perlakuan pemberian maserat buah mangrove $A$. marina sebesar $5,12-5,15$ menunjukkan nilai yang sama dengan nilai $\mathrm{pH}$ ikan segar yang diukur sebagai bahan perbandingan yaitu sebesar 5,12. Sesuai dengan Fardiaz (1992) menyatakan bahwa $\mathrm{pH}$ yang baik untuk ikan yang diawetkan antara 2,0-5,5 sedangkan pH antara 6,0-8,0 merupakan media yang baik untuk pertumbuhan mikroorganisme.

\section{Kadar Protein}

Protein memiliki fungsi utama sebagai pembentuk struktur sel dan biokatalisator untuk reaksi-reaksi kimia dalam metabolisme makhluk hidup (Sari, 2011). Menurut Ethel (2004) bahwa absorpsi protein ikan lebih tinggi dibandingkan daging sapi, ayam, dan lain-lain. Hal Ini disebabkan karena ikan mempunyai serat-serat protein yang lebih pendek dari pada serat-serat protein daging sapi atau ayam (Sajogyo, 2000).

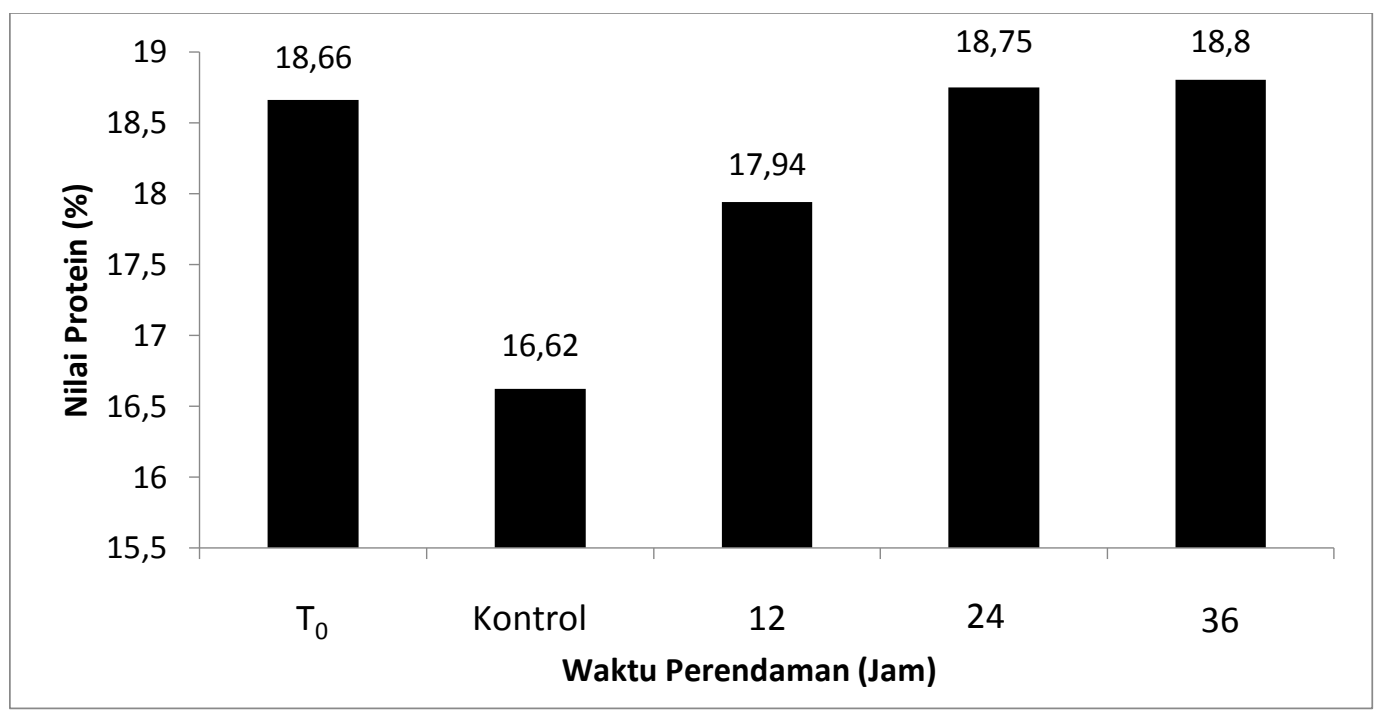

Gambar 2. Grafik nilai protein pada ikan nila (Oreochromis sp.)

Berdasarkan Gambar 2, kadar protein ikan nila yang direndam dalam maserat buah mangrove $A$. marina berkisar antara 17,94-18,8. Menurut Pratama et al., (2014), tinggi rendahnya nilai protein yang terukur dapat dipengaruhi oleh besarnya kandungan air yang hilang (dehidrasi) dari bahan. Penurunan kadar protein selama masa penyimpanan juga dapat dipengaruhi oleh terjadinya penurunan $\mathrm{pH}$ pada saat pembentukan asam laktat sehingga terjadi penurunan daya ikat air dan banyak air yang 
bergabung dengan protein. Pernyataan ini diperkuat oleh Soeparno (1994) bahwa penurunan $\mathrm{pH}$ yang cepat, misalnya karena pemecahan ATP yang cepat, akan meningkatkan kontraksi aktomiosin dan menurunkan daya mengikat protein.

\section{Uji Organoleptik}

Pengujian organoleptik sering disebut dengan sifat subyektif atau sifat indrawi atau lebih dikenal dengan uji sensoris karena penilaiannya juga didasarkan pada rangsangan sensoris dengan menggunakan kepekaan alat indra manusia (Rahayu, 1998). Secara umum, hasil uji organoleptik menunjukkan bahwa ikan nila yang tidak direndam dalam maserat buah mangrove (kontrol) menghasilkan nilai parameter organoleptik yang lebih rendah dibandingkan dengan ikan nila yang diaplikasikan dengan maserat buah mangrove, sedangkan maserat yang secara umum efektif adalah maserat hasil maserasi selama 12 jam. Hal ini dikarenakan semakin lama waktu ekstraksi, maka jumlah rendemen yang dapat diikat oleh pelarut semakin sedikit, yang disebabkan karena menguapnya sebagian kandungan buah mangrove $A$. marina sehingga senyawa-senyawa berupa tannin, flavonoid, alkaloid, saponin, dan terpenoid yang dihasilkan maserat yang didapat cenderung menurun (Bustan dkk., 2008).

\section{Mata}

Hasil uji organoleptik mata pada ikan nila dengan pemberian maserat buah mangrove $A$. marina dapat dilihat pada Gambar 3.

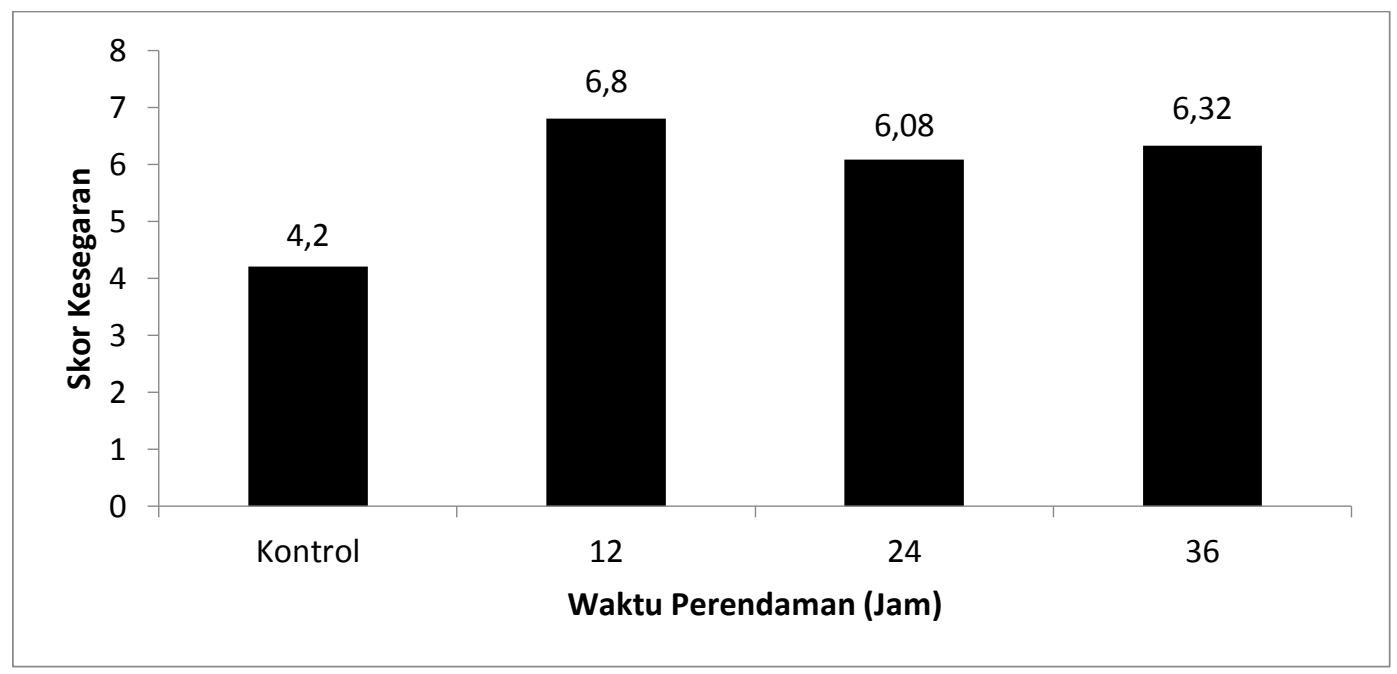

Gambar 3. Nilai organoleptik mata ikan nila selama penyimpanan dingin

Hasil uji organoleptik mata ikan nila semua perlakuan untuk parameter mata berkisar antara 6,08-6,8, secara deskriptif terletak pada 
kategori bola mata agak keruh, pupil berubah keabu-abuan, kornea agak keruh. Adanya perubahan organoleptik mata dikarenakan mata ikan nila sudah mengalami kemunduran mutu yang disebabkan oleh pertumbuhan bakteri pembusuk, yang ditandai dengan bola mata yang cekung, pupil putih susu dan kornea keruh. Hal ini diperkuat oleh pernyataan Ilyas (1983), bahwa salah satu akibat dari mulai berkembangnya bakteri adalah mata jadi terbenam dan pudar sinarnya.

\section{Insang}

Hasil uji organoleptik ingsang pada ikan nila dengan pemberian maserat buah mangrove $A$. marina dapat dilihat pada Gambar 4.

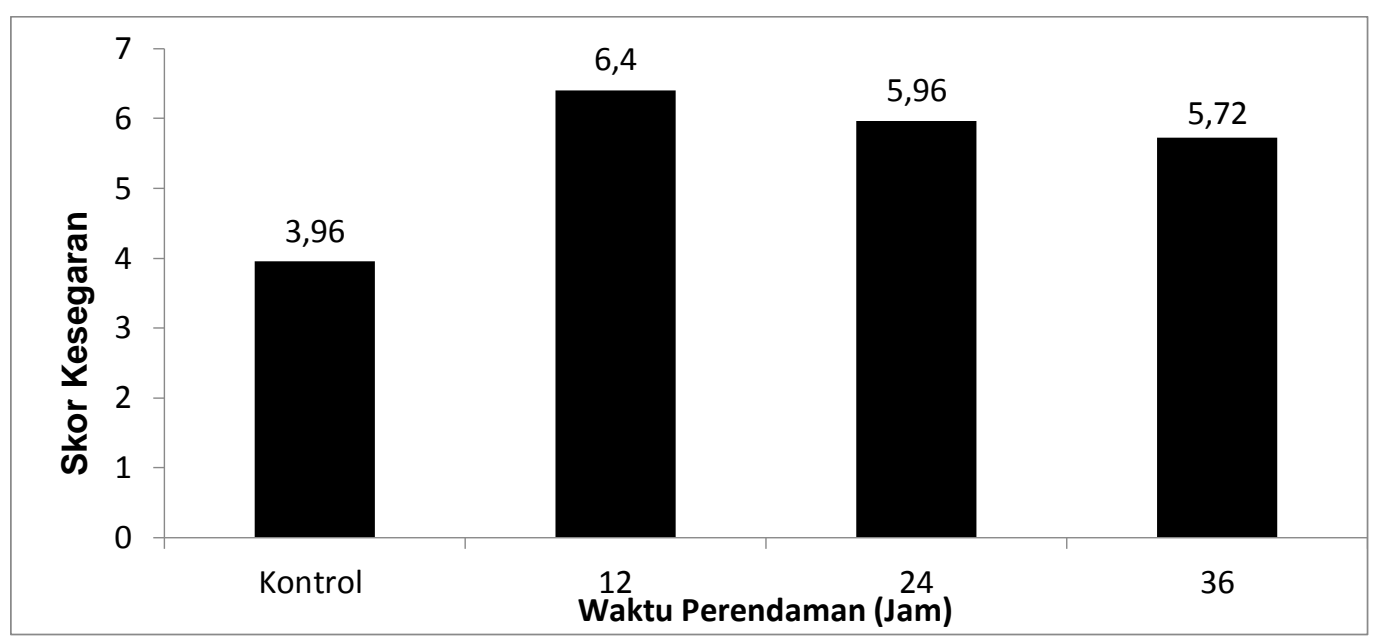

Gambar 4. Nilai organoleptik insang ikan nila selama penyimpanan dingin

Hasil uji organoleptik insang ikan pada semua perlakuan berkisar antara 6,4 (merah agak kusam, sedikit lendir) - 5,72 (mulai ada perubahan warna, merah kecoklatan, sedikit lendir). Penurunan nilai organoleptik insang diduga disebabkan oleh ikan nila yang disimpan dalam penyimpanan dingin. Hal ini sesuai dengan pernyataan Wibowo dan Yunizal (1998), penyimpanan ikan segar dengan menggunakan es atau sistem pendinginan yang lain memiliki kemampuan yang terbatas untuk menjaga kesegaran ikan, biasanya $10-14$ hari.

\section{Lendir Permukaan Badan}

Hasil uji organoleptik pada parameter lendir permukaan badan selama masa penyimpanan dingin dapat dilihat pada Gambar 5. 


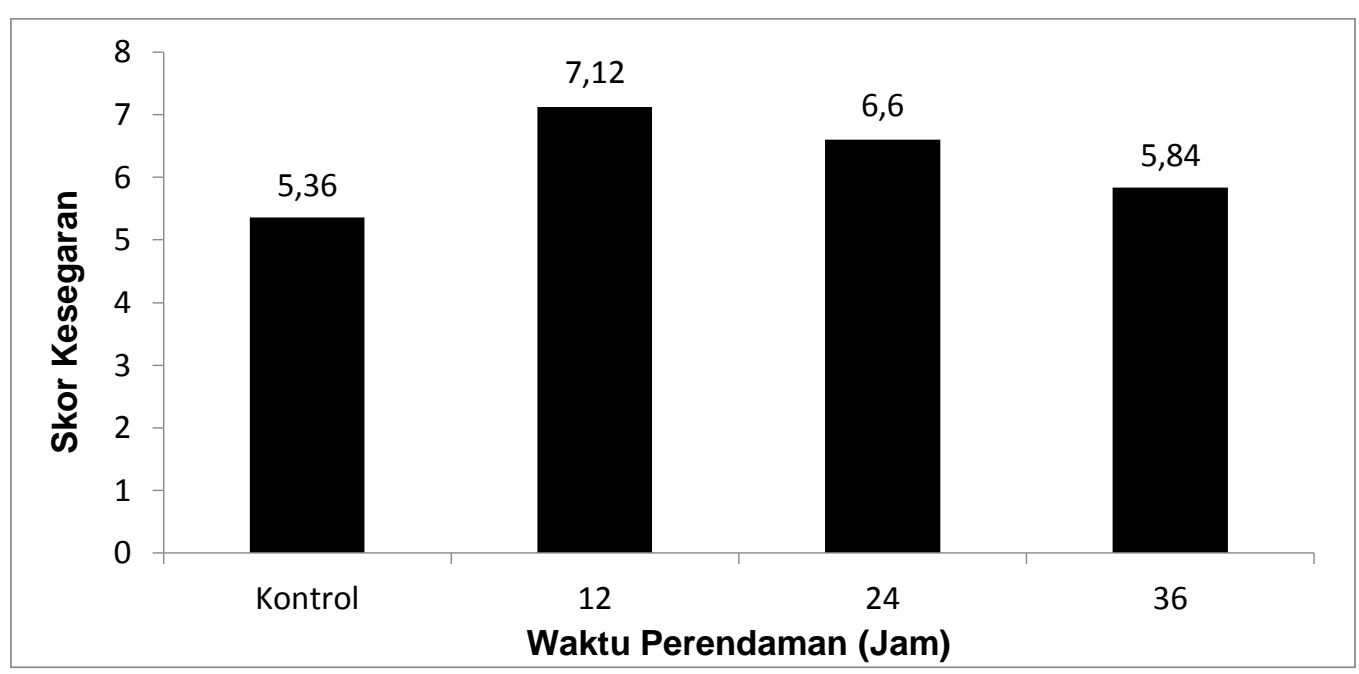

Gambar 5. Nilai organoleptik lendir permukaan badan ikan nila selama penyimpanan dingin

Hasil uji organoleptik lendir permukaan badan ikan pada semua perlakuan berkisar antara 7,12 (lapisan lendir mulai agak keruh, warna agak putih, kurang transparan) - 5,84 (lendir tebal menggumpal, mulai berubah warna putih, keruh). Penurunan nilai organoleptik lendir permukaan badan diduga disebabkan oleh adanya aktivitas bakteri dan enzim selama masa penyimpanan. Menurut Heruwati dkk., (1985) lendir yang timbul disebabkan oleh proses perkembangan bakteri pada kulit dan daging ikan.

\section{Daging}

Hasil uji organoleptik pada parameter daging selama masa penyimpanan dingin dapat dilihat pada Gambar 6.

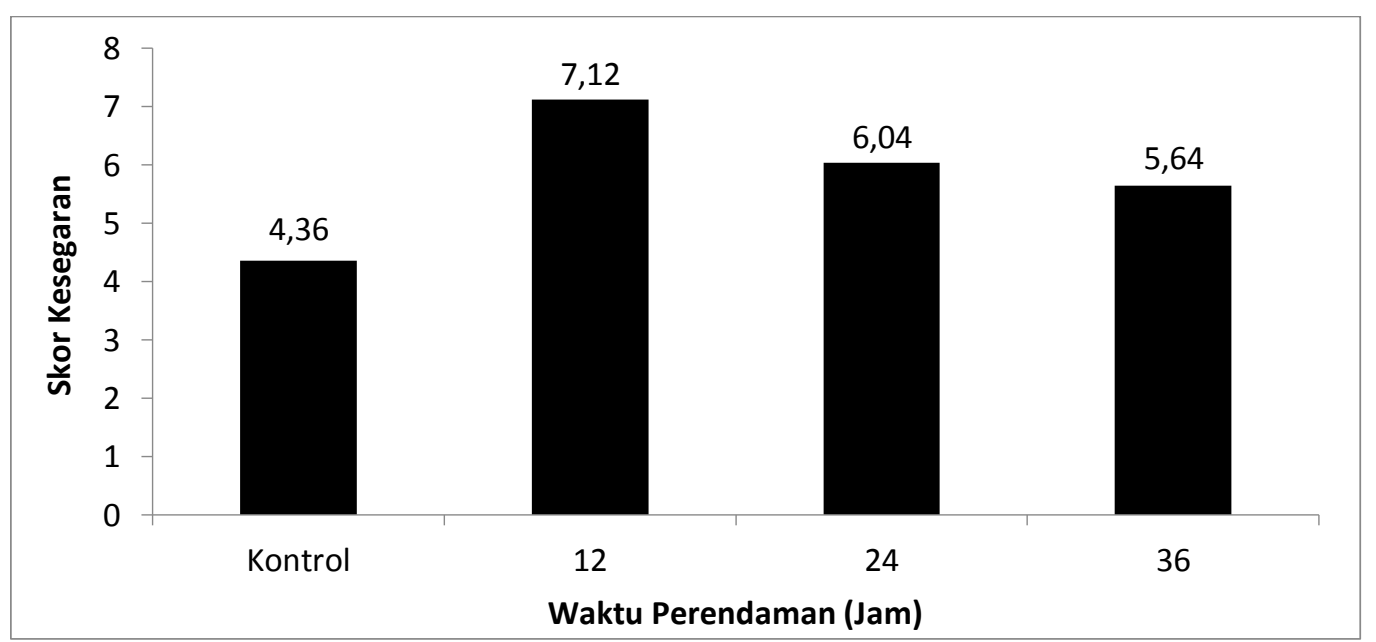

Gambar 6. Nilai organoleptik daging ikan nila selama penyimpanan dingin 
Hasil uji organoleptik daging ikan pada semua perlakuan berkisar antara 7,12 (sayatan daging sedikit kurang cemerlang, spesifik jenis, tidak ada pemerahan sepanjang tulang belakang, dinding perut daing utuh) 5,64 (sayatan daging mulai pudar, banyak pemerahan sepanjang tulang belakang, dinding perut agak lunak). Hal tersebut menunjukkan bahwa kesegaran ikan mulai menurun. Kekenyalan pada daging berkurang karena terputusnya benang-benang daging dan rusaknya dinding sel pada ikan (Hadiwiyoto, 1993).

\section{Bau}

Hasil uji organoleptik pada parameter bau selama masa penyimpanan dingin dapat dilihat pada Gambar 7.

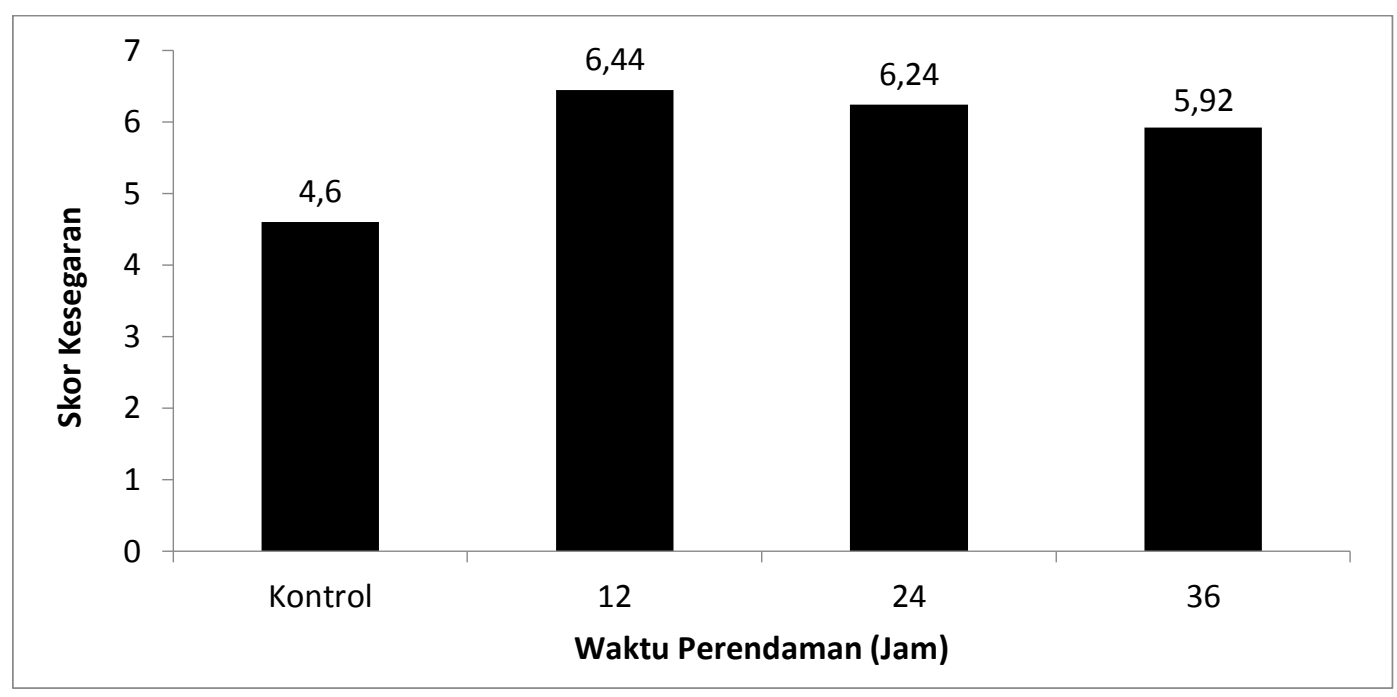

Gambar 7. Nilai organoleptik bau ikan nila selama penyimpanan dingin

Menurut Husni et al., (2014), bau pada ikan disebabkan adanya senyawa-senyawa volatil yang berbau seperti amoniak, sehingga mengakibatkan skor orgaoleptik bau menjadi rendah. Pada saat pembusukan, komponen penyusun aroma ikan yang khas akan hilang dan amoniak lebih banyak terbentuk sehingga bau amoniak lebih mendominasi (Ditjenkan, 1991). Bau amoniak merupakan hasil penguraian protein dari aktivitas bakteri, sehingga hubungan jumlah bakteri dengan amoniak yang terbetuk berbanding lurus (Litaay $d k k$., 2017). Menurut Widiastuti (2007), kehadiran mikroorganisme pada ikan juga mengakibatkan perubahan bau.

\section{Tekstur}

Hasil uji organoleptik pada parameter tekstur selama masa penyimpanan dingin dapat dilihat pada Gambar 8. 


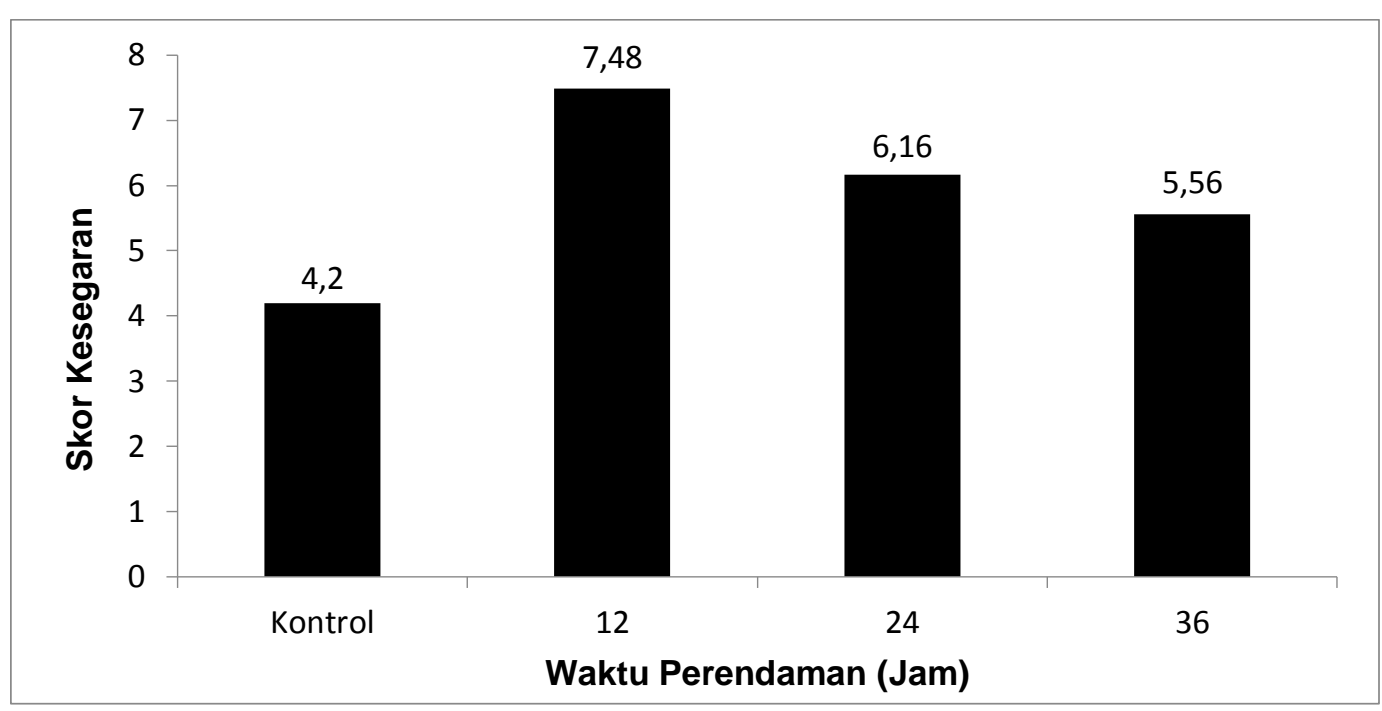

Gambar 8. Nilai organoleptik tekstur ikan nila selama penyimpanan dingin

Hasil uji organoleptik tekstur ikan pada semua perlakuan berkisar antara 7,48 (agak padat, agak elastis bila ditekan dengan jari, sulit menyobek daging dari tulang belakang) - 5,56 (agak lunak, kurang elastis bila ditekan dengan jari, agak mudah menyobek daging dari tulang belakang). Perubahan tekstur daging ikan menjadi lembut dan lunak disebabkan karena adanya proses autolisis yang menimbulkan perubahan pada daging, seperti daging menjadi lunak dan mudah lepas dari tulang (Gustini dkk., 2014).

\section{KESIMPULAN}

Hasil maserasi buah mangrove $A$. marina yang paling optimal digunakan sebagai pengawet alami ikan segar adalah hasil maserasi selama 12 jam. Berdasarkan hasil analisis sidik ragam (ANOVA) menunjukkan bahwa pemberian berbagai maserat buah $A$. marina mempengaruhi daya simpan ikan. Hal ini menunjukkan bahwa buah mangrove $A$. marina dapat digunakan sebagai pengawet alami ikan.

\section{DAFTAR PUSTAKA}

Bloom, J. H. 1988. Chemical and Physical Water Quality Analysis a Report and Practical at Training at Faculty of Fisheries. Universitas Brawijaya. Malang.

Bustan, M.D., R. Febriani, dan H. Pakpahan. 2008. Pengaruh Waktu Ekstraksi dan Ukuran Partikel Terhadap Berat Oleoresin Jahe yang diperoleh Dalam Berbagai Jumlah Pelarut Organik (Methanol). Jurnal Teknik Kimia, 15 (4) : 16-26. 
Ethel, S. 2004. Anatomi dan Fisiologi untuk Pemula. Buku Kedokteran. EGC. Jakarta.

Fardiaz, S. 1992. Mikrobiologi Pangan 1. Gramedia Pustaka Utama. Jakarta. hal. 97-129.

Hadiwiyoto, S. 1993. Teknologi Pengolahan Hasil Perikanan. Jilid I. Penerbit : Liberty, Jakarta.

Heruwati, E.S., Kamarijani, dan Soedarsono, J. 1985. Pindang Bandeng Kudus. II. Perubahan Mutu yang terjadi selama penyimpanan. Lap. Penel. Teknol. Perik, (41) : 15-20.

Husni, A., Utadi, dan A. Hakim. 2014. Penggunaan Ekstrak Rumput Laut Padina sp. untuk Peningkatan Daya Simpan Filet Nila Merah yang Disimpan pada Suhu Dingin. Jurnal Agritech, 34 (3) : 239-246.

Ilyas, S. 1983. Teknologi Refrigasi Hasil Perikanan. Jilid I. Teknik Pendinginan Ikan. CV : Paripurna, Jakarta.

Litaay, C., S.H. Wisudo., J. Haluan, dan H. Bambang. 2017. Pengaruh Perbedaan Metode Pendinginan Terhadap Mutu Organolpetik Ikan Cakalang Segar. Jurnal IImu dan Teknologi Kelautan Tropis, 9 (2) : 717-726.

Pariansyah, A. 2017. Aplikasi Maserat Buah Mangrove Avicennia marina Sebagai Pengawet Alami Ikan Nila Segar. Skripsi. Program Studi Ilmu Kelautan Universitas Bengkulu, Bengkulu.

Pratama, R. I., I. Rostini, dan E. Liviawaty. 2014. Karakteristik Biskuit dengan Penambahan Tepung Tulang Ikan Jangilus (Istiophorus sp.). Jurnal Akuatika, 5 (1) : 30-39.

Rahayu, W.P. 1998. Petunjuk Penilaian Organoleptik. Fakultas Teknologi Pertanian Institut Pertanian Bogor, Bogor.

Sajogyo. 2000. Menuju Gizi Baik Uang Merata di Pedesaan dan di Kota. Gajah Mada University, Yogyakarta.

Sari, M.K. 2011. Analisis Usaha Pengolahan Ikan Asin Di Kabupaten Cilacap. Fakultas Pertanian. Universitas Sebelas Maret, Surakarta.

Soeparno. 1994. Ilmu dan Teknologi Daging. Gadjah Mada University Press, Yogyakarta.

Subasheree, S.L.W. 2010. Skrining Fitokimia dan Uji Aktivitas Antibakteri dari Kulit Buah Sentul (Sandoricum Koetjape) Terhadap Beberapa 
Bakteri Secara In Vitro. Skripsi. Fakultas Farmasi. Universitas Sumatera Utara, Medan.

Susilo, C. 2013. Pemanfaatan Pohon Mangrove Api-Api (Avicennia spp.) sebagai bahan Pangan dan Obat. Fakultas Kehutanan. Institut Pertanian Bogor, Bogor.

Wibowo, dan S. Yunizal. 1998. Penanganan Ikan Segar. Pusat Penelitian dan Pengembangan Perikanan. Jakarta.

Widiastuti, I.M. 2007. Sanitasi dan Mutu Kesegaran Ikan Konsumsi Pada Pasar Tradisional di Kotamadya Palu. Jurnal Agroland, 14 (1) : 7781. 